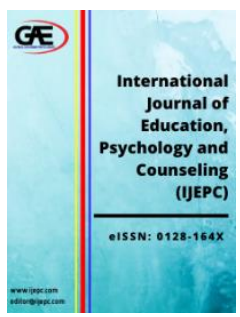

\author{
INTERNATIONAL JOURNAL OF \\ EDUCATION, PSYCHOLOGY \\ AND COUNSELLING \\ (IJEPC) \\ www.ijepc.com
}

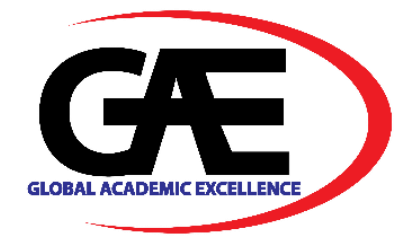

\title{
A QUASI-EXPERIMENTAL STUDY ON THE EFFECTS OF A SELF-REGULATION-BASED ESL WRITING INSTRUCTIONAL MODULE ON MALAYSIAN SECONDARY SCHOOL STUDENTS' ESL WRITING PERFORMANCE
}

\author{
Jacinta Karen Juin ${ }^{1}$, Wardatul Akmam Din ${ }^{2 *}$, Ameiruel Azwan Ab Aziz ${ }^{3}$, Suyansah Swanto ${ }^{4}$ \\ 1 Faculty of Education \& Psychology, Universiti Malaysia Sabah, Malaysia \\ Email: dp1811039t@student.ums.edu.my \\ 2 Faculty of Education \& Psychology, Universiti Malaysia Sabah, Malaysia \\ Email: wardadin@ums.edu.my \\ 3 Academy of Language Studies, Universiti Teknologi Mara, Malaysia \\ Email: amierul@uitm.edu.my \\ $4 \quad$ Faculty of Education \& Psychology, Universiti Malaysia Sabah, Malaysia \\ Email: suyansah@ums.edu.my \\ Corresponding Author
}

\section{Article Info:}

Article history:

Received date: 11.09 .2021

Revised date: 10.10 .2021

Accepted date: 15.11 .2021

Published date: 30.11 .2021

\section{To cite this document:}

Juin, J. K., Din, W. A., Aziz, A. A. A., \& Swanto, S. (2021). A QuasiExperimental Study On The Effects Of A Self-Regulation-Based Esl Writing Instructional Module On Malaysian Secondary School Students' Esl Writing Performance. International Journal of Education, Psychology and Counseling, 6 (43), 156-168.

\begin{abstract}
:
Self-regulation is a necessary component of developing skilled writers. Selfregulation, on the other hand, is rarely discussed in Malaysian ESL contexts, particularly in terms of ESL writing. This quasi-experimental study evaluated an ESL writing instructional module based on self-regulation with the goal of improving secondary school students' narrative writing. This study, which was conducted as part of a larger study, presented the results of the pilot study. The findings indicated statistically significant improvements in the students' overall writing performance and in each of the four components of writing, namely content, communicative appropriateness, organisation, and language. The findings indicated that the self-regulation-based writing instructional module was effective at improving students' overall writing performance and performance in each of the four writing aspects. Future studies should include a larger sample size, extend the duration of the intervention, and investigate additional variables such as gender and level of proficiency.
\end{abstract}

Keywords:

ESL, Writing, Self-Regulation, SRSD, Secondary School 
This work is licensed under $\underline{\text { CC BY } 4.0}$

\section{Introduction}

Writing remains the most significant skill used for interaction, communication, and survival, thus making it vital for people of all ages to master. In the Malaysian education context, most teachers perceived that ESL writing is one of the weakest skills possessed by students in Malaysia (Fauziah Hassan \& Nita Selamat, 2002; Ghabool, Mariadass, \& Kashef, 2012; Mimi Estonella Mastan, Nooreiny Maarof, \& Mohamed Amin Embi, 2017). Despite having learned the language for eleven years, secondary school students frequently fail to produce the writing that is expected at their level (Li \& Razali, 2019). Existing literatures related to ESL writing revealed that writing in English poses difficulties for Malaysian secondary school students in terms of proficiency and behaviour.

One of approaches towards developing skilled writers is to foster effective self-regulation skills. Skilled writers possess high self-regulation, and there is a link between writing improvement and self-regulation (Graham \& Harris, 2005). Although self-regulation plays an important role in the development of skilled writers, its potentials were not fully explored in the Malaysian ESL secondary school classroom context. This raised the question of whether Malaysian secondary school students could benefit from an ESL writing intervention based on self-regulation. Therefore, the purpose of this study was to determine if the effects of a self-regulation-based writing instructional module are statistically significant and could improve secondary school students' writing performance.

As self-regulation is essential for developing skilled writers, the significance of this study would be to develop and evaluate an additional or alternative approach in improving students' writing performance and preparing them for their post-secondary school endeavours.

\section{Literature Review}

The body of literature on ESL writing, intervention, and the role of self-regulation in the development of writing abilities is extensive and expanding. The review of literature in this study focuses on three areas: the context of ESL writing in secondary schools in Malaysia; the function of self-regulation in writing; and the SRSD model as an instructional strategy.

\section{ESL Writing in the Malaysian Secondary School Context: Situation and Challenges}

Writing is one of the language skills examined in Malaysian schools, and in addition to classroom training, support tools such as after-school programmes and writing intervention modules were used to assist with writing education. Nonetheless, these modules were examination-oriented and utilised a practice-drills strategy, as the interventions designed were focused on improving students' writing scores. Writing in Malaysian secondary schools is assessed using a curriculum-aligned and standardised rubric that encompasses four assessment components, namely content, communicative appropriateness, organisation, and language - instructional efforts aimed at improving students' writing performance are therefore concentrated on these four components. 


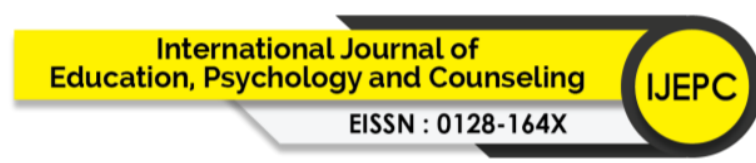

Volume 6 Issue 43 (November 2021) PP. 156-168 DOI 10.35631/IJEPC.643014

Special Issue: Issues and Challenges in English Education

Despite the fact that English language is taught in Malaysian secondary school classrooms, students in Malaysia continue to struggle with writing in a second language such as English. Writing-related concerns frequently centred around issues of proficiency and language, such as the influence of one's native or first language (Maros, Kim Hua, \& Salehuddin, 2007); grammar issues; and limited, imprecise vocabulary use (Fareed, Ashraf, \& Bilal, 2016; Fauziah Hassan \& Nita Selamat, 2002; Ghabool et al., 2012). Malaysian students have also been shown to be fearful of writing (Akhtar, Hassan, \& Saidalvi, 2020), to have low selfefficacy (Parilah Shah, Wan Hamiah Wan Mahmud, Din, Aminuddin Yusof, \& Khalid Mat Pardi, 2011), and to exhibit behaviours consistent with an inefficient self-regulation capacity (Juin, Swanto, \& Din, 2021a). Additionally, unlike excellent writers, the majority of students lacked the ability to manipulate strategies that would aid them in managing their writing process (Zimmerman \& Risemberg, 1997).

As one of the components tested in the English language subject for secondary school students, many tools and intervention programmes have been developed to supplement classroom instruction and to assist students in improving their writing skills. In the Malaysian secondary school context, tools and intervention programmes for writing are primarily focused on providing feedback (Yeo, 2018), utilising collaborative writing approaches (Gimenez \& Thondhlana, 2012; Mohammad Khatib \& Meihami, 2015; Tanyeli Zeki \& Kuter, 2018), sentence construction and grammar (Murugiah, 2013; Soo Eun Chae, 2012), as well as the use of digital media and social media (Barrot, 2016; Kok Eng Tan, Melissa L.Y. $\mathrm{Ng}$, \& Kim Guan Saw, 2010).

In Malaysia, writing skills are taught through a process writing approach. Despite the fact that the process writing approach contains implicit self-regulation features, the self-regulation mechanisms offered in popular writing models such as the process writing approach have been underutilised.

\section{Self-Regulation in Writing: Roles and Significance Towards Writing Development}

Self-regulation is one of the elements required in the development of skilled writers. According to Zimmerman, Bonner, and Kovach (1996), a student is defined as self-regulated when they are metacognitively, motivationally, and behaviourally active participants in their own learning process. One way of promoting self-regulation is to provide strategy-focused writing instruction, which would help writers with executive control over their own writing process (López, Torrance, Rijlaarsdam, \& Fidalgo, 2017).

Writing requires a strategic approach, and good writers are known to exploit writing-related and self-regulation strategies. The role of self-regulation in writing is vital (Zimmerman \& Risemberg, 1997), yet it might be moderate (Graham \& Harris, 1997), and the importance of encouraging young writers to develop their self-regulation skills related to writing could be beneficial for teaching and learning of writing.

Despite the role of self-regulation in developing writing skills, its potential was not fully exploited in the Malaysian secondary school classroom context. This could be due to the examination-oriented system in the Malaysian education context, hence making selfregulation strategies related to instruction difficult. 


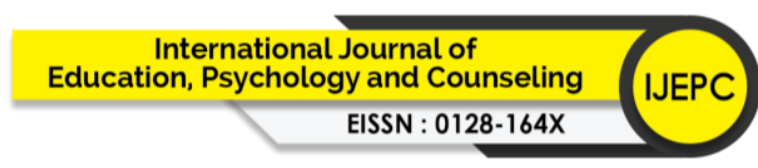

Volume 6 Issue 43 (November 2021) PP. 156-168 DOI 10.35631/IJEPC.643014

Special Issue: Issues and Challenges in English Education

Self-Regulation-Based Intervention: The SRSD Model As An Instructional Strategy.

One of the well-documented and empirically proven self-regulation-based intervention models for writing is the Self-Regulation Strategies Development model (SRSD). The SRSD model is one of the teaching approaches that teachers could employ to teach and help students learn a variety of writing strategies (Santangelo, Harris, \& Graham, 2008a). Initially, the model was developed to help learners with learning difficulties to write (Harris, Graham, \& Mason, 2007). The use of the SRSD model in instruction is founded on the premise that writing is challenging due to the minimised planning and other self-regulatory processes, which includes self-monitoring, self-evaluation, self-reinforcement, and self-instruction (Graham, 2006). The SRSD model is a criterion-based module where instruction is continued until the students can practice the strategies taught independently (Rogers \& Graham, 2020). There are six recursive, non-linear stages of the SRSD model. Table 1 illustrates the six stages of the SRSD model.

\begin{tabular}{|c|c|c|}
\hline Stage & & Description \\
\hline $\begin{array}{l}\text { Develop } \\
\text { knowledge }\end{array}$ & background & $\begin{array}{l}\text { The first or preliminary stage of the model focuses on } \\
\text { identifying the pre-requisite skills required for the task and } \\
\text { to assess whether the students possess the required skills. } \\
\text { This phase aims to ensure that students will understand, } \\
\text { learn, and apply the strategy taught successfully. }\end{array}$ \\
\hline Discuss it & & $\begin{array}{l}\text { This stage's purpose is to ensure that students are open and } \\
\text { willing to learn the strategy, besides introducing the concept } \\
\text { of progress monitoring by requiring students to identify at } \\
\text { least one aspect of writing that they wish to improve. After } \\
\text { this stage, the steps of the intended strategy will be } \\
\text { introduced. }\end{array}$ \\
\hline
\end{tabular}

Model it At this stage, the teacher models the strategy taught through think aloud or other modelling strategy that the teacher deemed useful for teaching the strategy. The strategy taught may be modelled several times until students were able to perform it on their own or with minimal guidance.

Memorise it Memorising the strategy is one of the key stages of the SRSD model where students familiarise with the steps in the strategy so that automaticity of using the strategy can be achieved.

Support it At this stage, teacher scaffold the instruction through the use of peers, feedback, and positive reinforcement as students gradually assume responsibility for the new strategy.

Independent work This is the practice stage where students apply and practice the strategy they were taught.

Source : Adapted from Santangelo, Harris, \& Graham (2008)

The SRSD model has been commonly used in contexts of learners with learning difficulties (Graham, Harris, \& Larsen, 2001; Santangelo, Harris, \& Graham, 2008b) and has also been explored in normal-achieving students' contexts (Danoff, Harris, \& Graham, 1993; Limpo \& Alves, 2013a). 


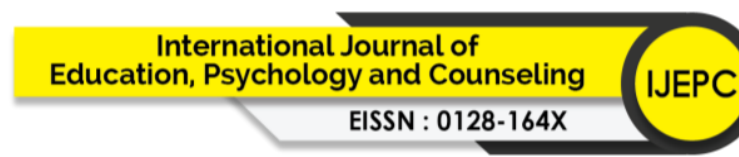

Volume 6 Issue 43 (November 2021) PP. 156-168

DOI 10.35631/IJEPC.643014

Special Issue: Issues and Challenges in English Education

Although the SRSD model is widely researched in areas of second language writing, there is a scarcity of studies done in the secondary school context in Malaysia. Most studies related to the SRSD model were focused on learners with learning difficulties and behavioural problems (Harris et al., 2007; Jozwik, Cuenca-Carlino, Mustian, \& Douglas, 2019; Ozsowska, Wyeth, Carrington, \& Ashburner, 2021). The majority of these studies were conducted in a native speaker context, and studies in non-native speakers are limited, with only a few studies conducted in the local, non-native context (Aminatun \& Marmanto, 2018; Mimi Estonella Mastan \& Noreiny Maarof, 2014).

Studies related to SRSD also focused on essay length and students' writing quality (Danoff et al., 1993), but have not explored other linguistic elements assessed in the actual classroom.

\section{Research Questions}

The five research questions of this study are as follows: -

a. Is there a significant difference in the students' overall writing performance after the intervention?

b. Is there a significant difference in the content element of the students' essay after the intervention?

c. Is there a significant difference in the communicative appropriateness element of the students' essay after the intervention?

d. Is there a significant difference in the organisation element of the students' essay after the intervention?

e. Is there a significant difference in the language element of the students' essay after the intervention?

\section{Hypothesis}

The hypothesis being tested in this quasi-experimental study are as follows:-

$\mathrm{H}_{\mathrm{o}}$ There is no significant difference between the students' overall writing performance after the intervention.

$\mathrm{H}_{\mathrm{o}}$ There is no significant difference in the students' content elements score after the intervention.

$\mathrm{H}_{\mathrm{o}}$ There is no significant difference in the students' communicative appropriateness scores after the intervention.

$\mathrm{H}_{\mathrm{o}}$ There is no significant difference in the students' organisation element scores after the intervention.

$\mathrm{H}_{\mathrm{o}}$ There is no significant difference in the students' language scores after the intervention.

\section{Methodology}

\section{Research design}

This quasi-experimental research involved 35 Form 2 students in a government school in Sabah, Malaysia. This was a pilot study as part of a larger study conducted by the author and her colleagues. The study was conducted in a government secondary school before a pandemic-caused nationwide movement restriction order was implemented in March 2020. 


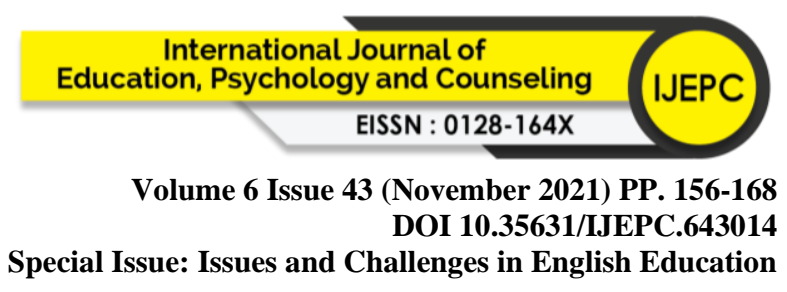

\section{Participants}

The participants comprised of one English language teacher and 35 Form 2 students. The teacher involved in this study has been teaching the English subject for 8 years. The students' selected for this study comprised of 17 male students and 18 female students. The students' levels of proficiency consisted of low to intermediate English proficiency levels, and this categorisation was based on the students' most recent English language test. The students were selected using non-random, purposive sampling based on the following criteria: a) Must be from a lower form class; b) must have a low to medium proficiency level. Table 2 shows the students' brief demographic information.

Table 2. Students Demographic

\begin{tabular}{ll}
\hline Gender & Number of students \\
\hline Male & 17 \\
\hline Female & 18 \\
\hline
\end{tabular}

After the selection, students were randomly assigned by the researcher to be in the control and intervention group.

\section{Instrument}

The instrument for this study was the self-regulation-based ESL writing module developed by the researcher (see Juin, Swanto, \& Din, 2021b). The module combined the six recursive stages of the SRSD model (Harris, Santangelo, \& Graham, 2008) with the process writing stages (Harmer, 2004). The module's six units' activities comprised of writing-related and self-regulation strategies which relates to the process writing stages. The module comprised of six units, which the teacher went through according to the units provided. The unit began with task analysis, where the students were required to analyse the task provided using an activity named "Wreck-A-Task". Students analysed the task provided by identifying relevant keywords, understanding the task requirement, and labelling the keywords using different coloured pens. The second unit dealt with the goal-setting element, which is another selfregulation strategy provided in the module. The goal-setting activity required the students to set three goals related to their overall performance and two task-related goals. The third unit corresponded with the planning unit, and in this unit, the teacher demonstrated a planning strategy for the students. The fourth unit is the drafting unit, where the teacher scaffolds the students' writing skills through related writing strategies. The fifth unit is related to revising and editing, and here students are taught how to use revising strategies as a form of selfmonitoring. The final unit is where students attempt to do independent work and the teacher will assess their work and determine the next plan. Students revisit their goals set earlier and discuss what strategies work for them and what doesn't.

Table 3. Contents of the Self-regulation-based Writing Module

\begin{tabular}{lll}
\hline Unit & Content & Teaching \& Learning Activities \\
\hline Unit $1-$ Wreck- & Task-analysis & $\begin{array}{l}\text { Students are taught how to analyse their task } \\
\text { before beginning to write. }\end{array}$ \\
A-Task & $\begin{array}{l}\text { Students are taught how to set their own personal } \\
\text { goals which relates to their overall target of } \\
\text { Unit 2- Goal- } \\
\text { setting }\end{array}$ & $\begin{array}{l}\text { achievement and task-related goals. Each student } \\
\text { is required to set a minimum of three goals: one }\end{array}$ \\
\hline
\end{tabular}




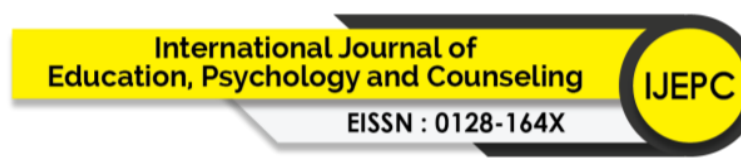

Volume 6 Issue 43 (November 2021) PP. 156-168

DOI 10.35631/IJEPC.643014

Special Issue: Issues and Challenges in English Education is their overall target goal and two for taskrelated goal.

Unit 3 - Planning Planning and setting Students are exposed to planning strategies and Develop the students' through the use of graphic organisers, mindbackground background mapping tools, and outline templates.

knowledge knowledge of the task

Unit 4-Drafting Drafting the essay Students are taught how to draft their essays using drafting templates and language-related activities e.g. using hooks for their essay.

Unit 5 - Revising Revising and Students are taught revising and editing strategies and Editing editing the essay such as ARMS and COPS, as well as using a checklist to evaluate their work before submission.

Unit $6-$ Publishing stage This unit allows students to display their Independent Work understanding and to apply their knowledge of the strategies unto their written work. The teacher assesses the students' work and observe which strategies needed to be focused on.

Prior to the intervention, the students were taught using the process writing approach which was the default teaching approach used in the classroom. Before the study began, the teacher involved in this study was provided with training on how to use the module before implementing it in his classroom.

\section{Implementation and Data Analysis}

The module was implemented over the course of four weeks. Each lesson was allocated 40 minutes per period, and there were five lesson periods allocated for the English language subject. A post-test was carried out at the end of the four weeks. The intervention was carried out during lessons within school operating hours. The data collection for this study was carried out before the nationwide lockdown was imposed. Table 4 shows the module intervention cycles and essay topics covered during the study.

Table 4: Module Intervention Cycles and Essay Topics

\begin{tabular}{|c|c|c|c|}
\hline Week & $\begin{array}{l}\text { Research/Module } \\
\text { activities }\end{array}$ & Essay Topic & Lesson period \\
\hline $\begin{array}{l}\text { Week } \\
1\end{array}$ & $\begin{array}{l}\text { Pre-test administered to } \\
\text { students }\end{array}$ & $\begin{array}{l}\text { An Unforgettable } \\
\text { Event }\end{array}$ & $\begin{array}{l}\text { Pre-test was conducted for } 40 \\
\text { minutes. }\end{array}$ \\
\hline $\begin{array}{l}\text { Week } \\
2\end{array}$ & $\begin{array}{l}\text { Unit } 1 \text { - Wreck A Task } \\
\text { Unit } 2 \text { - Goal-setting } \\
\text { Unit } 3 \text { - Planning }\end{array}$ & My Dream Holiday & $\begin{array}{l}35-40 \text { minutes lesson period } \\
\text { allocated for each unit. }\end{array}$ \\
\hline $\begin{array}{l}\text { Week } \\
3\end{array}$ & $\begin{array}{l}\text { Unit } 4 \text { - Drafting } \\
\text { Unit } 5 \text { - Revise and Edit } \\
\text { Unit } 6-\text { Independent } \\
\text { Work }\end{array}$ & & $\begin{array}{l}35-40 \text { minutes lesson period } \\
\text { allocated for each unit. }\end{array}$ \\
\hline $\begin{array}{l}\text { Week } \\
4\end{array}$ & $\begin{array}{l}\text { Post-test administered to } \\
\text { students }\end{array}$ & $\begin{array}{l}\text { A Moment to } \\
\text { Remember }\end{array}$ & $\begin{array}{l}\text { Post-test was conducted for } 40 \\
\text { minutes. }\end{array}$ \\
\hline
\end{tabular}




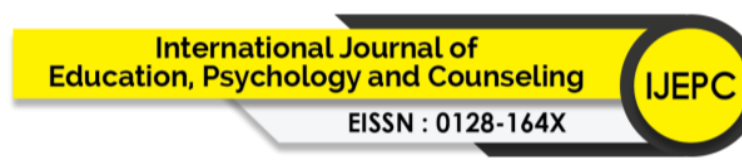

Volume 6 Issue 43 (November 2021) PP. 156-168

DOI 10.35631/IJEPC.643014

Special Issue: Issues and Challenges in English Education

A paired t-test was performed after the administration of the pre-and post-test to determine the changes before and after the intervention was administered. The students' essays were assessed using a standardised writing assessment rubric used in schools, which contains four linguistical elements, namely, content, communicative appropriateness, organisation, and language. The teacher or assessor tallied the total scores of each element as a final score at the end of the assessment. The full score for each composition is 20 points. The summary of the teaching and learning procedures during the intervention is shown in Table 5.

Table 5: Summary of the Teaching and Learning Procedures.

\begin{tabular}{|c|c|c|}
\hline Stage & Teaching activities & Learning activities \\
\hline Pre-Intervention & $\begin{array}{l}\text { Students were taught the } \\
\text { characteristics of descriptive essay } \\
\text { using default approach. }\end{array}$ & $\begin{array}{l}\text { Students learned the } \\
\text { characteristics of descriptive } \\
\text { essay using teacher's default } \\
\text { approach. }\end{array}$ \\
\hline Pre-testing & $\begin{array}{l}\text { Single } 40 \text { minutes session to plan and } \\
\text { compose a guided essay: An } \\
\text { Unforgettable Event. }\end{array}$ & $\begin{array}{l}\text { Students plan and compose } \\
\text { guided essay: An Unforgettable } \\
\text { Event. }\end{array}$ \\
\hline $\begin{array}{l}\text { Instructional } \\
\text { activities }\end{array}$ & $\begin{array}{l}\text { Students were taught using the } \\
\text { module activities which include } \\
\text { writing strategies and self-regulation } \\
\text { strategies i.e. task analysis and goal- } \\
\text { setting. }\end{array}$ & $\begin{array}{l}\text { Students learned how to plan, } \\
\text { draft, revise and edit their essay } \\
\text { and use self-regulation } \\
\text { strategies related to writing. }\end{array}$ \\
\hline $\begin{array}{l}\text { Instructional } \\
\text { similarities with } \\
\text { default approach }\end{array}$ & $\begin{array}{l}\text { Use all five stages of process writin } \\
\text { editing, and publishing. }\end{array}$ & g: planning, drafting, revising, \\
\hline $\begin{array}{l}\text { Instructional } \\
\text { differences with } \\
\text { default approach }\end{array}$ & $\begin{array}{l}\text { Self-regulation strategies were added } \\
\text { into the process writing phases. }\end{array}$ & $\begin{array}{l}\text { Students were taught to analyse } \\
\text { the task given and to set goals } \\
\text { in general and related to the } \\
\text { current task. }\end{array}$ \\
\hline
\end{tabular}

\section{Results}

The data collected from the pre- and post-test was tabulated in order to investigate the effectiveness of the self-regulation-based writing module on students' writing performance. The paired sample t-test was conducted to compare the students' writing performance before and after the self-regulation-based writing intervention. The paired t-test analysis results revealed that there was a statistically significant increase in the students' overall writing performance after the intervention was implemented in the classroom.

Table 6. Overall Writing Performance

\begin{tabular}{lllll} 
Time & Mean & SD & t-value & p-value $(<\mathbf{0 . 0 5})$ \\
\hline Pretest & 8.74 & 2.381 & -12.871 & .000 \\
\hline Posttest & 10.63 & 2.088 & &
\end{tabular}

Note: *Significant level $\mathrm{p}<0.05$

Table 6 displays the overall writing performance mean scores. Based on the results depicted above, the students' writing performance there were significant difference after the module was carried out. There was a statistically significant increase in the writing scores of the Copyright $\odot$ GLOBAL ACADEMIC EXCELLENCE (M) SDN BHD - All rights reserved 


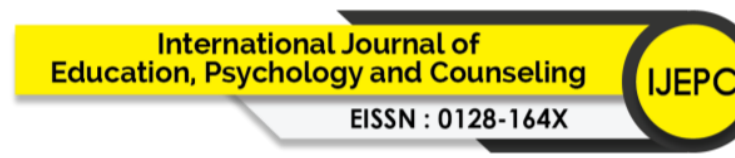

Volume 6 Issue 43 (November 2021) PP. 156-168 DOI 10.35631/IJEPC.643014

Special Issue: Issues and Challenges in English Education students after the intervention was performed $(\mathrm{M}=10.63, \mathrm{SD}=2.088)$ than before the intervention $(\mathrm{M}=8.74, \mathrm{SD}=10.63) ; \mathrm{t}(34)=-12.871, \mathrm{p}=.000$.

In terms of content, there was also statistically significant increase in the students' performance in the content element $(\mathrm{M}=0.486, \mathrm{SD}=0.612)$. The students' content scores significantly increased after the intervention $(\mathrm{M}=3.14, \mathrm{SD}=2.66)$ than before the intervention $(\mathrm{M}=2.66, \mathrm{SD}=0.684) ; \mathrm{t}(34)=-4.694, \mathrm{p}=.000$. Table 7 displays the content mean scores.

\section{Table 7. Content}

\begin{tabular}{lllll}
\hline Time & Mean & SD & t-value & p-value $(<\mathbf{0 . 0 5})$ \\
\hline Pretest & 2.66 & .684 & -4.694 & .000 \\
\hline Posttest & 3.14 & .648 & & \\
\hline
\end{tabular}

Note: *Significant level $\mathrm{p}<0.05$

As for communicative competence, there was statistically significant increase in the students' communicative appropriateness level after the intervention $(\mathrm{M}=3.14, \mathrm{SD}=0.648)$ compared to before the intervention $(\mathrm{M}=2.66, \mathrm{SD}=0.684) ; \mathrm{t}(34)=-4.694, \mathrm{p}=.000$. Table 8 displays the communicative appropriateness pre-test and post-test score.

Table 8. Communicative Appropriateness

\begin{tabular}{lllll}
\hline Time & Mean & SD & t-value & p-value $(<\mathbf{0 . 0 5})$ \\
\hline Pretest & 2.49 & .781 & -5.667 & .000 \\
& & & & \\
\hline Posttest & 2.97 & .568 & & \\
\hline
\end{tabular}

Note: *Significant level $\mathrm{p}<0.05$

In terms of organisation, the results showed a statistically significant difference after the intervention $(\mathrm{M}=2.97, \mathrm{SD}=0.568)$ compared to before the intervention $(\mathrm{M}=2.49, \mathrm{SD}=0.781)$; $\mathrm{t}(34)=-5.667, \mathrm{p}=.000)$. Table 9 displays the organisation scores.

Table 9. Organisation

\begin{tabular}{lllll}
\hline Time & Mean & SD & t-value & p-value $(<\mathbf{0 . 0 5})$ \\
\hline Pretest & 2.03 & .664 & -5.351 & .000 \\
\hline Posttest & 2.49 & .612 & & \\
\hline
\end{tabular}

Note: *Significant level $\mathrm{p}<0.05$

As for language, there is also a statistically significant difference after the intervention, $(\mathrm{M}=2.06, \mathrm{SD}=0.639)$ compared to before the intervention $(\mathrm{M}=1.69, \mathrm{SD}=0.631)$; $\mathrm{t}(34)=-$ $4.018, \mathrm{p}=0.000)$. Table 10 displays the language scores.

Table 10. Language

\begin{tabular}{lllll}
\hline Time & Mean & SD & t-value & p-value $(<\mathbf{0 . 0 5})$ \\
\hline Pretest & 1.69 & .631 & -4.018 & .000 \\
\hline Posttest & 2.06 & .639 & & \\
\hline
\end{tabular}

Note: *Significant level $\mathrm{p}<0.05$ 


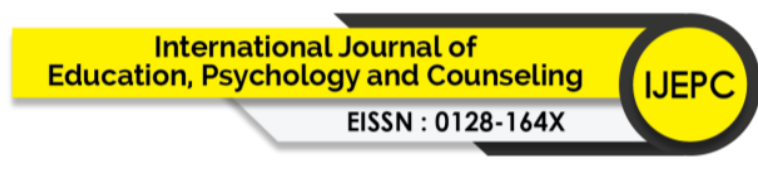

Volume 6 Issue 43 (November 2021) PP. 156-168

DOI 10.35631/IJEPC.643014

Special Issue: Issues and Challenges in English Education

The results of the paired t-test recorded a significant finding as the overall writing performance and four elements depicted $\mathrm{p}<0.05$ in all the results. The null hypotheses were therefore rejected.

\section{Discussion}

The results of the study suggest that the self-regulation-based writing instruction module was effective and depicted statistically significant effects in increasing the overall writing performance of the participants. In the short period of the intervention, it was found that the students' writing test scores increased across all four subscales assessed. The findings resonated with other studies (Cuenca-Carlino \& Mustian, 2018; Danoff et al., 1993; Limpo \& Alves, 2013b) where the SRSD model when carried out in normal instruction, was found to be effective in increasing students' writing quality. However, being a criterion-based model, the SRSD model used as an instructional strategy for the module was found to be tedious and time-consuming for Malaysian classrooms where examinations are still heavily emphasised. Despite the significant results in this study, the criterion-based nature of the SRSD model needed to be adapted in order to adapt to the examination-oriented nature of the Malaysian education system.

Although the students showed increased performance scores, there were some limitations. Firstly, the intervention time period was considered too brief for other observations, for example, students' strategy use, to be conducted. The limited and brief time period was due to the impending lockdown initiated by the worsening pandemic. Secondly, there were no participants' perspectives taken into consideration, as participants' perspectives could add depth to the findings. This limitation was also attributed to the sudden closure of schools, which prompted the researchers to recalibrate their research plans.

Based on the discussion above, it may be recommended for future studies to do the following: firstly, include a larger population for generalization; secondly, prolong the intervention duration, and thirdly, to investigate how other variables would affect the results; for example, gender and levels of proficiency. Another recommendation is to replicate the study with the addition of qualitative approaches so that the study can be extended to include the participants' perspectives.

\section{Conclusion}

To recapitulate this study, in order to help students develop their writing skills, it is critical to foster their ability for self-regulation, in addition to improving students' language mastery. The self-regulation-based ESL writing intervention module for secondary school learners was evaluated and found to be effective in improving students' overall writing performance as well as content, communicative appropriateness, organisation, and language.

\section{References}

Akhtar, R., Hassan, H., \& Saidalvi, A. (2020). The effects of ESL student ${ }^{\text {ee }}$ s attitude on academic writing apprehensions and academic writing challenges. International Journal of Psychosocial Rehabilitation, 24(5), 5404-5412. https://doi.org/10.37200/IJPR/V24I5/PR2020247 


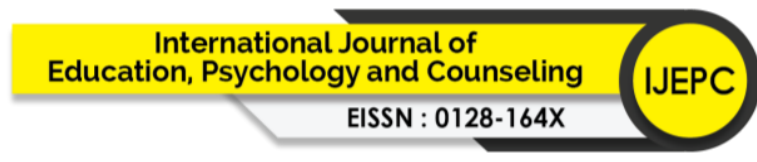

Volume 6 Issue 43 (November 2021) PP. 156-168 DOI 10.35631/IJEPC.643014

Special Issue: Issues and Challenges in English Education

Barrot, J. S. (2016). Using Facebook-based e-portfolio in ESL writing classrooms: impact and challenges. Language, Culture and Curriculum, 29(3), 286-301. https://doi.org/10.1080/07908318.2016.1143481

Binti, A., \& Zahidi, M. (2012). Self-regulation in English language learning: Case studies of six Malaysian undergraduates.

Cuenca-Carlino, Y., \& Mustian, A. L. (2018). Self-Regulated Strategy Development: Connecting Persuasive Writing to Self-Advocacy for Students with Emotional and Behavioral Disorders. Behavioral Disorders, 39(1), 3-15. https://doi.org/10.1177/019874291303900102

Danoff, B., Harris, K. R., \& Graham, S. (1993). INCORPORATING STRATEGY INSTRUCTION WITHIN THE WRITING PROCESS IN THE REGULAR CLASSROOM: EFFECTS ON THE WRITING OF STUDENTS WITH AND WITHOUT LEARNING DISABILITIES. Journal of Reading Behavior, 25(3). Retrieved from https://journals.sagepub.com/doi/pdf/10.1080/10862969009547819

Dyah Aminatun, Ngadiso, \& Marmanto, S. (2018). Applying PLEASE Strategy to Teach Writing Skill to Students with Different Linguistic Intelligences. Teknosastik, 16(1), 34-40.

Fareed, M., Ashraf, A., \& Bilal, M. (2016). ESL Learners' Writing Skills: Problems, Factors and Suggestions. Journal of Education \& Social Sciences, 4(2), 83-94. https://doi.org/10.20547/jess0421604201

Fauziah Hassan, \& Nita Selamat. (2002). Why Aren't Students Proficient in ESL: The Teachers' Perspective. THE ENGLISH TEACHER, 31, 107-123.

Ghabool, N., Mariadass, M. E. A., \& Kashef, S. H. (2012). Investigating Malaysian ESL Students' Writing Problems on Conventions, Punctuation, and Language Use at Secondary School Level. Journal of Studies in Education, 2(3). https://doi.org/10.5296/jse.v2i3.1892

Gimenez, J., \& Thondhlana, J. (2012). Collaborative writing in engineering: Perspectives from research and implications for undergraduate education. European Journal of Engineering Education, 37(5), 471-487. https://doi.org/10.1080/03043797.2012.714356

Graham, S. (2006). Strategy instruction and the teaching of writing. In C. MacArthur, S. Graham, \& J. Fitzgerald (Eds.), Handbook of Writing Research. (pp. 187-207). Guilford Press.

Graham, S., \& Harris, K. R. (1997). Self-Regulation and Writing: Where Do We Go from Here? Contemporary Educational Psychology, 22(1), 102-114. https://doi.org/10.1006/ceps.1997.0920

Graham, S., \& Harris, K. R. (2005). Self-Regulated Strategy Development: Helping Students with Learning Problems Develop as Writers. The Elementary School Journal, 94(2), 169-181. https://doi.org/10.1086/461758

Graham, S., Harris, K. R., \& Larsen, L. (2001). Prevention and Intervention of Writing Difficulties for Students with Learning Disabilities. Learning Disabilities Research \& $\begin{array}{llll}\text { Practice } & \text { (Vol. 16). Retrieved from }\end{array}$ https://s3.amazonaws.com/academia.edu.documents/6001172/grahametal01.pdf?AWS AccessKeyId=AKIAIWOWYYGZ2Y53UL3A\&Expires $=1546992463 \&$ Signature $=\mathrm{Jn}$ 7Ouck0EIIfPPHrFI0PB874DWM\%3D\&response-content-disposition=inline\%3B filename\%3DPrevention_and_intervention_of_writi

Harmer, J. (2004). How to teach writing (16th ed.). Edinburg: Pearson. 


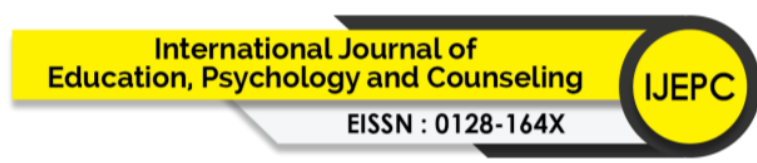

Volume 6 Issue 43 (November 2021) PP. 156-168 DOI 10.35631/IJEPC.643014

Special Issue: Issues and Challenges in English Education

Harris, K. R., Graham, S., \& Mason, L. H. (2007). Improving the Writing, Knowledge, and Motivation of Struggling Young Writers: Effects of Self-Regulated Strategy Development With and Without Peer Support. American Educational Research Journal, 43(2), 295-340. https://doi.org/10.3102/00028312043002295

Harris, K. R., Santangelo, T., \& Graham, S. (2008). Self-regulated strategy development in writing: Going beyond NLEs to a more balanced approach. Instructional Science, 36(5-6 EFFECTS OF CONSTR), 395-408. https://doi.org/10.1007/s11251-008-90629

Jozwik, S. L., Cuenca-Carlino, Y., Mustian, A. L., \& Douglas, K. H. (2019). Evaluating a self-regulated strategy development reading-comprehension intervention for emerging bilingual students with learning disabilities. Preventing School Failure, O(0), 1-12. https://doi.org/10.1080/1045988X.2018.1523126

Juin, J. K., Swanto, S., \& Din, W. A. (2021a). Characteristics and Teaching Challenges of Struggling Secondary School Writers: Assessing the need for self-regulation strategies based instruction. Journal of Educational Research and Indigenous Studies, $3(1), 13-22$.

Juin, J. K., Swanto, S., \& Din, W. A. (2021b). The Development of an SRSD-Based ESL Writing Instruction Module for Malaysian Secondary School Students. The Development of an SRSD-Based ESL Writing Instruction Module for Malaysian Secondary School Students ., 1(5), 453-467. https://doi.org/10.6007/IJARBSS/v11i5/9216

Kok Eng Tan, Melissa L.Y. Ng, \& Kim Guan Saw. (2010). Online activities and writing practices of urban Malaysian adolescents. System, 38(4), 548-559. https://doi.org/10.1016/j.system.2010.09.014

Li, K. L., \& Razali, A. B. (2019). Idea sharing: Process-based approach to writing in Malaysian english education. Pasaa, 58(December), 319-341.

Limpo, T., \& Alves, R. A. (2013a). Teaching planning or sentence-combining strategies: Effective SRSD interventions at different levels of written composition. Contemporary Educational Psychology, 38(4), 328-341. https://doi.org/10.1016/j.cedpsych.2013.07.004

Limpo, T., \& Alves, R. A. (2013b). Teaching Planning or Sentence-Combining Strategies: Effective SRSD Interventions at Different Levels of Written Composition. https://doi.org/10.1016/j.cedpsych.2013.07.004

López, P., Torrance, M., Rijlaarsdam, G., \& Fidalgo, R. (2017). Effects of direct instruction and strategy modeling on upper-primary students' writing development. Frontiers in Psychology, 8(JUN), 1-10. https://doi.org/10.3389/fpsyg.2017.01054

Maros, M., Kim Hua, T., \& Salehuddin, K. (2007). INTERFERENCE IN LEARNING ENGLISH: GRAMMATICAL ERRORS IN ENGLISH ESSAY WRITING AMONG RURAL MALAY SECONDARY SCHOOL STUDENTS IN MALAYSIA. Retrieved from http://ejournals.ukm.my/ebangi/article/viewFile/22041/6852

Mimi Estonella Mastan, Nooreiny Maarof, \& Mohamed Amin Embi. (2017). The effect of writing strategy instruction on ESL intermediate proficiency learners ' writing performance. Journal of Educational Research and Review, 5(5), 71-78.

Mimi Estonella Mastan, \& Noreiny Maarof. (2014). ESL Learners' Self-efficacy Beliefs and Strategy Use in Expository Writing. Procedia - Social and Behavioral Sciences, 116(May 2015), 2360-2363. https://doi.org/10.1016/j.sbspro.2014.01.573 


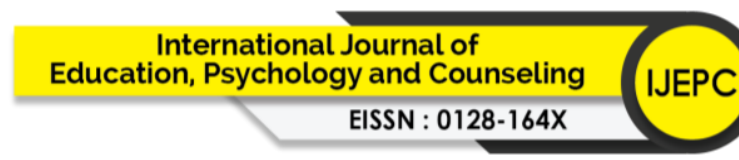

Volume 6 Issue 43 (November 2021) PP. 156-168 DOI 10.35631/IJEPC.643014

Special Issue: Issues and Challenges in English Education

Mohammad Khatib, \& Meihami, H. (2015). Languaging and Writing Skill: The Effect of Collaborative Writing on EFL Students' Writing Performance. Advances in Language and Literary Studies, 6(1). https://doi.org/10.7575/aiac.alls.v.6n.1p.203

Murugiah, M. R. (2013). Improving the 5th Formers' Continuous Writing Skills through the Creative Writing Module. Advances in Language and Literary Studies, 4(2), 7-12. https://doi.org/10.7575/aiac.alls.v.4n.2p.7

Ozsowska, A., Wyeth, P., Carrington, S., \& Ashburner, J. (2021). Using Assistive Technology with SRSD to support students on the autism spectrum with persuasive writing. British Journal of Educational Technology, 52(2), 934-959. https://doi.org/https://doi.org/10.1111/bjet.13063

Parilah Shah, Wan Hamiah Wan Mahmud, Din, R., Aminuddin Yusof, \& Khalid Mat Pardi. (2011). Self-Efficacy in the Writing of Malaysian ESL Learners. World Applied Sciences Journal, 15(Innovation and Pedagogy for Lifelong Learning), 8-11.

Regina Devi, G. A., \& Michael, P. J. (2013). Self-Regulated Strategy Development in Esl Writing for Academic Purposes. Retrieved from http://studentsrepo.um.edu.my/6211/1/Grace_PhD_Thesis_2013.pdf

Reinders, H. (2010). Towards a Classroom Pedagogy for Learner Autonomy: A Framework of Independent Language Learning Skills. This Journal Article Is Posted at Research Online. Reinders, H, 35(5), 35. https://doi.org/10.14221/ajte.2010v35n5.4

Rogers, L. A., \& Graham, S. (2020). Effectiveness of volunteer-led strategy instruction on the story writing of third grade students experiencing difficulties learning to write. Reading and Writing, 33(3), 761-782. https://doi.org/10.1007/s11145-019-09988-x

Santangelo, T., Harris, K. R., \& Graham, S. (2008a). Using self-regulated strategy development to support students who have "trubol giting thangs into werds." Remedial and Special Education, 29(2), 78-89. https://doi.org/10.1177/0741932507311636

Santangelo, T., Harris, K. R., \& Graham, S. (2008b). Using Self-Regulated Strategy Development to Support Students Who Have "Trubol Giting Thangs Into Werds." Remedial and Special Education, 29(2), 78-89. https://doi.org/10.1177/0741932507311636

Soo Eun Chae. (2012). Identifying Effective English L2 Writing Interventions: Emerging Trends and Issues in Recent Research. English Teaching, 67(4), 3-24. https://doi.org/10.15858/engtea.67.4.201212.3

Tanyeli Zeki, N., \& Kuter, S. (2018). Impact of collaborative and reflective writing activities on students' autonomy in writing. Quality \& Quantity, 52(S1), 343-360. https://doi.org/10.1007/s11135-017-0615-3

Yeo, M. (2018). When Less May Be More: Rethinking Teachers' Written Corrective Feedback Practices: Interview with Icy Lee. RELC Journal, 49(2), 257-261. https://doi.org/10.1177/0033688217738819

Zimmerman, B. J., Bonner, S., \& Kovach, R. (1996). Developing Self-Regulated Learners. Focus on Exceptional Children. Retrieved from http://library.lol/main/94C88724B8BFD5A735567B5972FCC8EF

Zimmerman, B. J., \& Risemberg, R. (1997). RESEARCH FOR THE FUTURE Becoming a Self-Regulated Writer: A Social Cognitive Perspective. Contemporary Educational Psychology, 22, 73-101. 